\title{
Postnatal Changes in Oxygen-Hemoglobin Affinity and Erythrocyte 2,3-Diphosphoglycerate in Piglets
}

\author{
Maria Delivoria-Papadopoulos, ${ }^{[25]}$ Ronald J. Martens, Robert E. Forster II, \\ and Frank A. Oski
}

Departments of Physiology and Pediatrics, University of Pennsylvania, School of Medicine, Philadelphia, Pennsylvania, USA

\section{Extract}

Serial changes in hemoglobin, hematocrit, erythrocyte (RBC) 2,3-diphosphoglycerate (2,3-DPG), and whole blood oxygen affinity were studied in piglets. In the newborn piglet, the $\mathrm{P}_{50}$ averaged $19.0 \mathrm{~mm} \mathrm{Hg}$ at birth and the erythrocyte 2,3-DPG was 1,670 $\mathrm{m} \mu \mathrm{mol} / \mathrm{ml} \mathrm{RBC}$ 's. Within $48 \mathrm{hr}$ of birth, these values had increased to $27.4 \mathrm{~mm} \mathrm{Hg}$ and $6,600 \mathrm{~m} \mu \mathrm{mol} / \mathrm{ml} \mathrm{RBC's,} \mathrm{respectively.} \mathrm{Normal} \mathrm{adult} \mathrm{values} \mathrm{were} \mathrm{reached} \mathrm{by} 1$ month of age. The $\mathrm{P}_{50}$ bore a direct relationship to the erythrocyte 2,3-DPG concentration.

\section{Speculation}

The mechanism triggering the rapid rise in erythrocyte 2,3-DPG and the abrupt increase in $\mathrm{P}_{50}$ in the newborn piglet remains unexplained. The rise in 2,3-DPG may be a result of alterations in plasma $\mathrm{pH}$, a sudden rise in plasma inorganic phosphate, or the presence of a metabolizable substrate such as dihydroxyacetone that was not present in the fetal environment. It remains to be determined whether the 2,3-DPG effect on $\mathrm{P}_{50}$ is a result of direct interaction with hemoglobin or a consequence of alterations in intracellular $\mathrm{pH}$. 
The goat was the first species in which differences between the oxygen affinity of maternal and fetal blood was observed (12). With the exception of the cat (16), in all species studied to date (3), the blood of the fetus has been found to have a higher affinity for oxygen than that of the mother. In man, the most mammalian species (goat, sheep, rabbit, lion, and dog). normal adult occurs during the first six months of life $\langle 2,8,9,10,11,16$, normal adul

Factors causing the postnatal decrease in blood oxygen affinity include the replacement of fetal by adult types of hemoglobin, alterations in red ceil hydrogen ion concentration, and changes in the concentra
organic phosphates such as 2,3 -diphosphoglycerate $(4,5,8)$.

The present study was conducted in an attempt to characterize the nature and time of the change in the whole blood oxygen affinity of piglets.

\section{MATERIALS AND METHOIDS}

Fifty-nine piglets, weighing 750 to 1350 grams at birth, from seven different litters were studied. In most instances, the animals were studied at birth, at 12 and 48 hours of life, 4,10 , and 17 days of age, and then weckly until two and one-half months of age. In addition, randomly selected
pigs were studied at 3,5 , and 12 months of age.

Six to ten milliliters of blood were obtained from each piglet by either cardiac or jugular vein puncture. The samples were collected in heparin and kept chilled in wet ice until the time of analysis.

In all samples, measurements of hemoglobin, hematocrit, percent fetal hemoglobin (21), red cell 2,3-diphosphoglycerate (2,3-DPG) concentration, and determination of the hemoglobin-oxygen equilibrium curve were performed.

Red cell 2,3-DPG was measured by a modification of the Krimsky (15) method previously described (8).

The oxygen-hemoglobin equilibrium curves were oltained by directly measuring the oxygen tension, $\mathrm{pH}$, and oxygen saturation following equilibration of whole blood lat a constant carbon cioxide tension) at varying oxygen contents. $\mathrm{C}$. The $\mathrm{P}$. which is the partial pressure of constant temperature of $370^{\circ}$ saturation, was then obtained from the regression line drawn through the data points of the steep part of the curve (8). All P s s were corrected to a pll of 7.40 using the Bohr factor of $-0.485(20)$ and temperature $39.6^{\circ}$ Centigrade (normal pig ten perature). Oxygen capacity in milliliters of oxygen per $100 \mathrm{ml}$ of blood was calculated by multiplication of the hemoglobin concentration in grams per $100 \mathrm{ml}$ by $1.39(23)$.

Samples of blood from each litter, as well as blood from the sow,
were employed for hemoglobin electrophoresis on starch gel, pH 8.6 (13).

\section{$\underline{\text { RFSULTS }}$}

The data obtained from the studies of 59 piglets is presented in Table

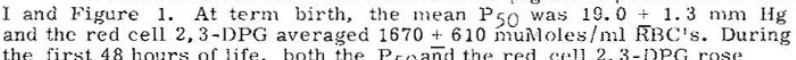
the first 48 hours of life, both the $P_{50}$ and the red cell $\left.2,3-1\right) P G$ rose rapidly and, by the end of the second day
6600 muMlos $/ m 1$ IRBC's respectively.

The $\mathrm{P}_{50}$ and the red cell 2,3-BPG concentration then gradualty increased and reached normal adult values by the third to fourth week of life. Between the fourth and tenth week of life, both the $\mathrm{P}_{50}$ and the red cell 2.3-

A highly significant direct relationship $(r-0.94)$ was observed between the $P_{50}$ value and the red cell 2,3-1)PG concentration (Figure 2).

At no time was fetal hemoglobin demonstrable by either alkali denaturation or hemoglobin electrophoresis.

\section{JISCUSSION}

In the piglct, unlike the human infant, it would appear that the decrease in hemoglobin-oxygen affinity that occurs in the postnatal period is entirely mediated via changes in red cell 2,3-DPG concentration. In the human,

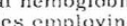
blood from both adult and fetil pigs employing techniques that included electrophoresis on starch block and cellulose acetate, chromatography on DEAEsephadex, denaturation by acid, alkali and heat, spectral analysis failed to reveal any significant differences (14). In addition, chromatography, electro phoresis, and finger-printing of separated alpha and non-alpha chains of feta pig hemoglobin failed to reveal the presence of any fetal type hemoglobin during any stage of development (22). These studies and the observed rapid in hemogiobin type are responsible for the alterations in red cell oxygen affinity that occur so promptly in the newborn period in the piglet.
In the piglet and the human infant, the affinity of hemoglobin for oxygen eventually reaches values that are even lower than that observed in the normal adult. In the pig, the normal adult values are achieved by 5 months of age,
while in the human these values may not be reached until pubescence (7).

Because of this apparent pure 2,3-DPG effect on modulating hemoglobin's affinity for oxygen, the piglet appears to be an ideal model for the affinity, and oxygen transport and delivery.

\section{SUMMARY}

Sequential measurements of red cell 2,3-diphosphoglyc:erate (2,3DPG) and whole blood oxygen affinity were performed in piglets from birth. These studies demonstrate a precise correlation between the 2, 3-1)P(i content curve and the absence of a fetal hemoglobin.

\section{RFFLRKENCES}

1. Anselmini, K. T. and Hoffman, $F$.: Die lirsehem des icterus

neonstorum. Archiv. Gynäk, 143:477, 1930.

2. Barron, D. H.: Postnatal changes in the oxygen capacity and dissociation Curve of the blood of lambs. Yale J. Biol. Med. 24:191, 1952.

3. Bartels, IL. Prematal respiration, North-Holland Publishing, Amster dam, 1970.

4. Battaglia, F. C., MeGaughey, H., Makowski, E. 1.. and Meschia, J. G.: Postnatal changes in 0 affinity of sheep red cells; a dual, role of

5. Baumann, R., Bauer, C. Al. and Rathschlag-Schacfer, A. M. Causes of the postnatal decrease of blood oxygen affinity in lambs. Resp. Physioi. 15:151, 1972.

6. Beutler, E. and Wood, $1 \ldots$.: The in vivo regeneration of red cell, 2,3diphosphoglyceric acid (IJPG) after transfusion of stored blood. J. Lab. Med., $74: 300,1969$

7. Card, R. T. and Brain, M. C.: The "anemia" of childhood: Physiologic

response to hyperphosphatemia. New ling. J. Med., 288:388, 19
8. Delivoria-Papadopoulos, M., Roncevic, N. P. and Oski, J. A. A

Postnatal changes in oxygen transport of term, premature, and sick infants: The role of red cell 2,3 -diphosphoglycerate and adult hemoglobin. Pediat. Res., 5:235, 1971 .

9. Dhindsa, D. S. and Metcalfe, J.: Respiratory characteristics of retal and newborn kittens. Fed. Proc., 32:350, 1973 (abstract).

10. Dhindsa, 1). S., Hoversland, A. S. and Templetou, J. W.: Postnatal changes in oxygen affinity and concentration of 2,3-diphosphoglycerate

in dog blood. Biol. Neonate, 20:226, 1972 .
11. Hasclhorst, (i. and Stromberger, K.: Uber den Gasgehalt des Nabelschnurblutes vor and nach der (ieburt des Kindes und über den Gasaustausch in der Plazenta. Z. (ieburtsh Ciynek., 10:49, 1931.

12. Iluggett, A. St. (i.: loctal blood-gas tensions ant gas transfusion
through the placenta of the goat. .J. Physiol. (Londion), 62:373, 1927.

13. Jonix, I. I1. P. and lluisman, T. H. J.: A laboratery manual on 1968 abnormal hemoglobins. Blackwell Scientific, 2nd edition, Oxford, 19
kleibauer, $\%$. and 'Tuatz, Ch.: (iibt es ein fetales Itamoglobin beim kleihauer, F. and Tuatz, Ch.: (iibt es ein fetales lfamoglobin beim
schwein? I. Analysen des lämoglobins. Res. kxper. Nied, 158:219,

1972 .
15rimsky, I.: D-2,3-diphosphoglycerate. In Nethods of Enzymatic Analysic, to

16. Novy, M. 3. and Parer, J. T. : Absence of high blood oxygen affinity in

the fetal cat. Resp. Physiol., 6:144, 1969

. Pome respiratory J. Appl. Physiol., 22:756, 1967 .

18. Parer, J. T. Hoversiand, A. S. and Netcalfe, J.: Comparative studies of the respiratory functions of mammalian blood. V.l. Young lion and tiger. lkesp. Physiol., 10:30, 1970.

19. Riegel, $k$. and Ruhrmann, G.: Über die Atemgastratusportlunktion des Blutes und die Jirythropoese junger Kanincheu. Acta liaemat., Basel, $32: 129,1964$

20. Severinghaus, J. W.: $13 l o o d$ gas calculator. J. Appl. Physiol., 21

1. Singer, K., Chernoff, A. I. and Singer, L.: Studies on abnormal hematologic disorders by means of alkali denaturation. Blood, $6: 413$, hemat
1951.
Tautz,

22. Tautz, Ch. and Kleihauer, J.: (iibt es ein fetales Hämoglobin beim schwein? II. Analysen des globins. Res. lexper. Med., 159:44, 1972 Weast, R. C.: Molar volume. In Handbook of Chemistry and Physics,

24. Supported by Public llealth Service Research (irants Numbers 5 RO1il) 1860-06 and HD01919 and Career Development Award Number 1-K04[11) 4771 .

25. Requests for reprints should be addressed to: Dr. Naria DelivoriaPapadopoulos, University of Pennsylvania Scheol of Mledicine, Department of Physiology, Philadelphia, Pennsylvania 19104, USA. 


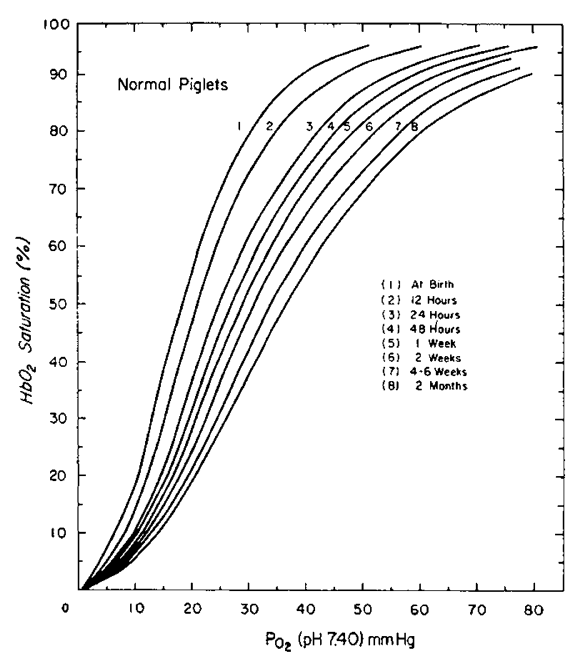

Figure 1. Oxygen-hemoglobin equilibrium curves of blood from piglets at different postnatal ages; each curve represents the mean value of the piglets studied in each age group.

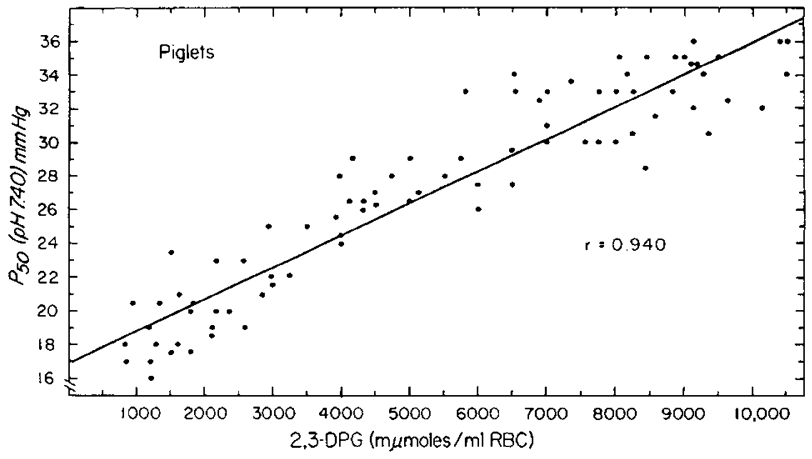

Figure 2. The $P_{50}$ and total red cell 2,3-diphosphoglycerate for all piglets at different postnatal ages.

$\underline{\text { TABLE I }}$

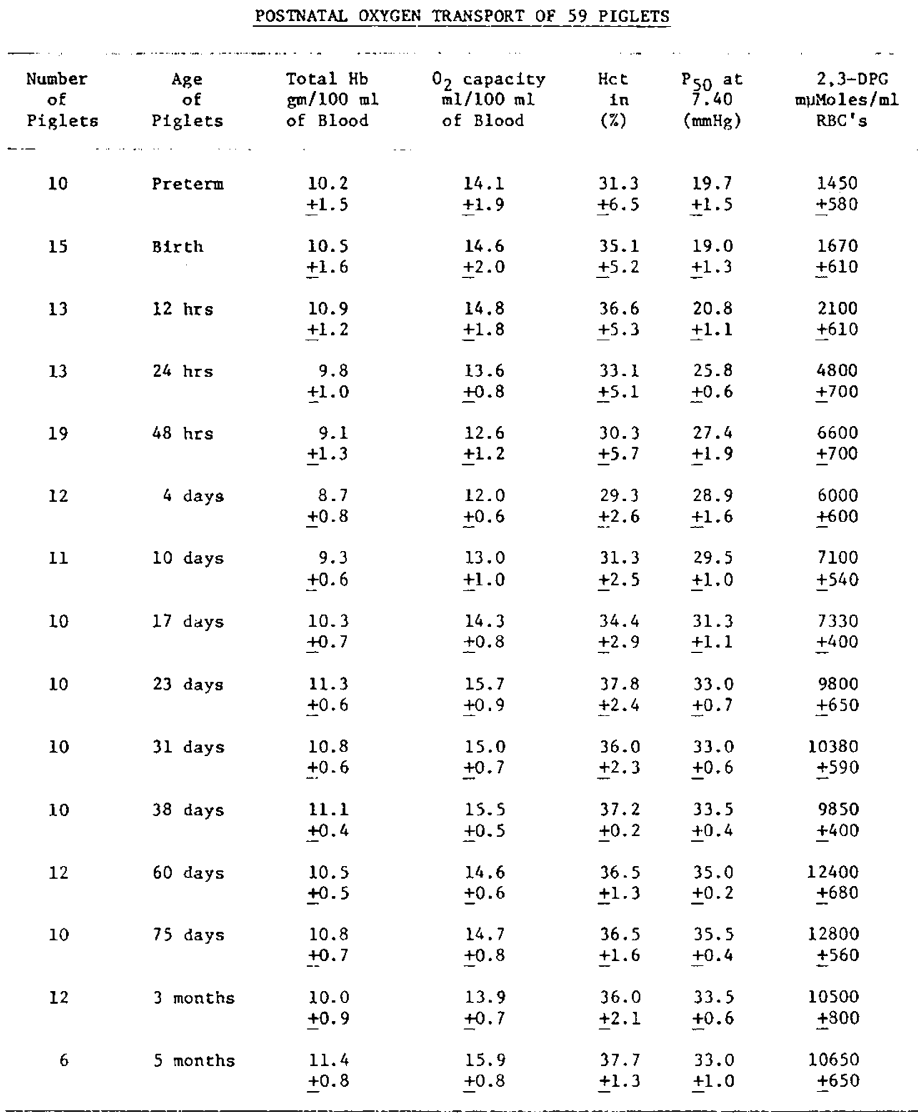

All values are given as mean \pm one standard deviation (SD). 